\title{
Association between blood coagulability and migraine
}

\author{
Ebtesam Mohamed Fahmy ${ }^{1}$, Mona Salah Eldin Hamdy², Reem Medhat Mahmoud ${ }^{1}$ and Haidy Elshebawy ${ }^{1 *}$
}

\begin{abstract}
Background: An association between migraine and stroke has been suggested for a long period, although conclusive evidence has not been reported. Several theories about hypercoagulability have been proposed for the association of ischemic stroke and migraine especially migraine with aura. This study aimed to assess blood coagulability in patients with migraine.

Results: Mean serum levels of protein S and anti-thrombin III were significantly lower in migraine patients compared to control subjects. Migraine patients showed abnormal MRI findings in the form of white matter hyper-intense lesions and ischemic foci compared to healthy controls. A significant negative correlation was detected between serum protein $\mathrm{C}$ level and intensity of migraine headache. Also, a significant correlation was found between deficient serum protein $\mathrm{S}$ and abnormal findings in brain MRI. Serum protein $\mathrm{C}$ deficiency is an independent predictor for migraine intensity grade.
\end{abstract}

Conclusions: There is an association between migraine and hypercoagulability, which may indicate increased risk of cerebral ischemic events in migraine patients and suggest adding prophylactic therapy to the management strategies of such patients.

Keywords: Migraine, Hypercoagulability, Protein C, Protein S, Anti-thrombin III

\section{Background}

Migraine is one of common primary headache disorders. It has a high disabling effect on personal and socioeconomic conditions. It is ranked as the third most prevalent disorder and seventh-highest specific cause of worldwide disability. Migraine has two major subtypes, migraine without aura (MO) and migraine with aura (MA) which is characterized mainly by transient focal neurological symptoms that usually precede or sometimes accompany the headache [1]. There is a complex bidirectional relation between migraine and stroke especially migraine with aura (MA), including migraine as risk factor of stroke, migraine as a complication of cerebral ischemia,

\footnotetext{
*Correspondence: Haidyshebawy@gmail.com

${ }^{1}$ Neurology Department, Faculty of Medicine, Cairo University, Cairo,

Egypt

Full list of author information is available at the end of the article
}

and migraine with cerebral ischemia sharing a common cause [2].

There are numerous theories linking migraine with hypercoagulability mainly related to cortical spreading depression (CSD) which may lead to weakening of the blood-brain barrier and endothelial damage, eliciting the inflammatory cascade in neurons and glial cells. These CSD-related changes create thrombophilic complications. Another theory suggested that migraine aura is equivalent to a transient ischemic attack (TIA), ischemia which is induced by CSD followed by platelet aggregation and microemboli may cause either aura or TIA [3].

Normal blood flow is maintained by the balance between the pro-coagulant and anti-thrombotic factors. A hypercoagulable state results from over activity of procoagulant factors or a deficiency in anti-coagulants [4].

Protein $\mathrm{C}$ and protein $\mathrm{S}$ are made in the liver and are vitamin $\mathrm{K}$ dependent; their deficiency is inherited as autosomal dominant traits in homozygous or 
heterozygous forms. Protein $\mathrm{C}$ acts to inactivate factor $\mathrm{V}$ and factor VIII [5]. It requires factor $\mathrm{S}$ as a cofactor and is activated by thrombin, when thrombin is bound to thrombomodulin [4].

As thrombin acts as a pro-coagulant, it also acts by negative feedback through activation of plasminogen to plasmin and stimulates the production of anti-thrombin (AT). Plasmin acts directly on the fibrin mesh and breaks it down. AT decreases the production of thrombin from prothrombin and decreases the amount of activated factor X [4].

Hypercoagulability disorders are characterized by the tendency to have thrombosis due to either acquired or inherited molecular defects. Genetic defects can now be identified in up to $30 \%$ of patients with venous thromboembolism. Protein $\mathrm{C}$, protein S deficiency and antithrombin III are of inherited thrombophilias which pose a higher risk for thrombosis [6].

This study was conducted to assess the relation between blood coagulability and migraine by estimating serum levels of protein $C$, protein $S$, and anti-thrombin III in a sample of Egyptian migraine patients and associated ischemic insults in the brain.

\section{Methods}

This is a case-control study conducted on 70 subjects ( 35 migraine patients and 35 healthy subjects). Patients were recruited from the headache clinic during the period from August 2020 to December 2020. The study proposal was revised and approved by the ethical committee of the Neurology Department, Faculty of Medicine, Cairo University in $8 / 7 / 2020$ with code MS-92-2020. The aim and nature of the study was explained for each participant before inclusion. Policy of data confidentiality was firmly followed. An informed written consent was obtained from all participants before enrollment.

Participants were distributed into two groups: Group (I), included 35 migraine patients and Group (II), included 35 age and sex-matched healthy individuals.

\section{Included in this study}

Migraine patients (of both sexes) diagnosed according to the International Classification of Headache Disorders criteria [1], their age ranged from 18 to 50 years.

\section{Excluded from this study}

Patients with headache other than migraine, neurological disorders that may affect the level of coagulation factors as stroke or idiopathic intracranial hypertension; patients with demyelinating, or other disorders with CNS pathology; patients with hypertension, dyslipidemia, diabetes mellitus, cardiac disease, patients with history of systemic diseases (malignancy, thyroid, autoimmune disorders, renal, and hepatic disorders) as these disorders can affect brain imaging and migraine intensity. Patients with psychiatric illness, patients receiving anticoagulants, estrogen containing oral contraceptive pills or hormonal therapy and pregnancy were also excluded.

Patients were submitted to: thorough clinical assessment according to the standard headache sheet officially used in department of neurology (blinded for peer review) which covers all headache characteristics regarding severity, duration, laterality, aura presence, frequency and interference with daily activities. Pain intensity was assessed by using Numeric Rating Scale for Pain (NRS) which requires the patients to rate their pain on a defined scale. For example, $0-10$ where 0 is no pain and 10 is the worst pain imaginable [7]. Magnetic resonant imaging (MRI) of brain (T1, T2 and FLAIR) was performed at the Diagnostic Radiology Department, Faculty of Medicine, Cairo University. Scans were done on a 1.5 Tesla Philips intera scanner (Brand: Philips, Model: 1.5 Tesla Philips intera scanner, made in United states) and measurement of Protein C, Protein S and anti-thrombin III levels: 2 $\mathrm{ml}$ of venous blood was collected by routine venipuncture under complete aseptic condition into blue top (Sodium Citrate) vacutainer in 1:9 ratio of $3.2 \%$ sodium citrate solution to whole blood. The tubes were inverted immediately several times to gently mix the blood with the anticoagulant and transferred to the lab in the original tubes. Citrated blood was centrifuged at $3000 \mathrm{rpm}$ for $15 \mathrm{~min}$ to collect platelet-poor plasma that was stored frozen at $-20{ }^{\circ} \mathrm{C}$ till time of testing. Frozen plasma was rapidly thawed within $10 \mathrm{~min}$ at $37^{\circ} \mathrm{C}$, gently mixed and tested within 8 h. Serum levels of Protein C, Protein S and anti-thrombin III were assayed using fully automated coagulometer, Sysmex CS-5100 (brand: Siemens, manufacturer name: Siemens Healthineers, made in Germany, model: Sysmex CS-5100). It measures the change in transmitted light through the reaction cuvette during the coagulation process. Light from the halogen lamp is dispersed in 340, 405, 575, 660 and $800 \mathrm{~nm}$ wavelengths by five different filters [8].

Controls were submitted to magnetic resonant imaging (MRI) of brain (T1, T2 and FLAIR) and measurement of Protein C, Protein S and anti-thrombin III levels.

\section{Statistical analysis}

Pre-coded data were entered in the computer using Microsoft Office Excel software program for Windows 2019, then transferred to the Statistical Package for the Social Sciences (SPSS version 26) (IBM Corp., Armonk, NY, USA). Data were summarized using mean, standard deviation, median, minimum and maximum in quantitative data and using frequency (count) and relative frequency (percentage) for categorical data. Comparisons 
between quantitative variables were done using the nonparametric Kruskal-Wallis and Mann-Whitney tests. For comparing categorical data, Chi-square $\left(\chi^{2}\right)$ test was performed. Exact test was used instead when the expected frequency is less than 5 . Correlations between quantitative variables were done using Spearman correlation coefficient. Linear regression analysis was done to predict protein $\mathrm{C}, \mathrm{S}$ using significant variables. $p$ Values less than 0.05 were considered as statistically significant.

\section{Results}

In the patients group, the age ranged from 18 to 48 years with a mean age of $30.80 \pm 7.00$ years, 28 patients $(80 \%)$ were females and seven patients $(30 \%)$ were males. In the control group, the age ranged from 18 to 49 years with mean age of $28.26 \pm 7.25$ years; 27 subjects $(77.1 \%)$ were females and 8 subjects (22.9\%) were males. Both groups were matched with regard to mean age and sex distribution ( $p=0.114,0.77$, respectively). The clinical and laboratory characteristics of migraine headache are represented in Table 1.

Regarding the radiological findings: 28 patients $(80 \%)$ had normal brain MRI, 4 migraine patients $(11.4 \%)$ had leukoaraoisis, while 3 patients had ischemic foci $(8.6 \%)$ in brain MRI. All control subjects (100\%) have normal brain imaging.

Regarding the laboratory results: the range and mean values of serum levels of protein $C$, protein $S$ and antithrombin III levels in groups I and II are represented in Table 2.

The mean serum levels of protein $\mathrm{S}$ and anti-thrombin III were significantly lower in migraine patients compared to control subjects ( $p=0.009,0.024$, respectively). However, there was no statistical difference between both groups as regards mean serum level of protein $C$ $(p=0.411)$ (Table 2). There was a high statistically significant difference between migraine patients and controls regarding abnormal brain MRI findings (leukoaraiosis and ischemic foci) $(p=0.011)$ (Table 3$)$.

According to presence of aura, migraine patients were subdivided into: migraine with aura (MA) and migraine without aura (MO). No statistically significant difference was found between MA and MO with regard to either mean or percentage of serum levels of protein $C$, protein S or anti-thrombin III (Table 4). No significant difference was found between both groups with regard to brain MRI findings $(p=0.691)$.

There was a significant negative correlation between migraine intensity and serum level of protein $C$ $(p=0.017, r=-0.399)$, however, no significant correlation was detected between serum level of protein $C$ with either age, disease duration or headache frequency $(p$-value $>0.05)$ (Table 5). No significant correlation was

Table 1 Clinical and laboratory characteristics of migraine headache in the patients group

\begin{tabular}{ll}
\hline Headache characteristics & $\begin{array}{l}\text { Number } \\
\text { of patients } \\
(n=35)\end{array}$ \\
\end{tabular}

Duration of the disease
Less than 6 years
$6-10$ years
More than 10 years
Type of migraine
With aura
Without aura
Frequency of attacks/month
$3-10$ attacks
More than 10 attacks
Duration of attack without medications
4 to less than $24 \mathrm{~h}$
24 to less than $48 \mathrm{~h}$
48 to less than $72 \mathrm{~h}$
Laterality
Right side
Left side
Both
Intensity (according to NRS)
$4-7^{\circ}$
$8-10^{\circ}$

Associated symptoms

Nausea

Photophobia

Phonophobia

Dizziness

\section{1}

10

14

Precipitating and aggravating factors

\section{Emotional stress}

Noise

Light or sunlight

Fatigue

Missed meals

Certain smell

Relieving factors

Quiet and darkness

Sleep

Simple analgesics

Protein C

Normal

Low

Protein S

Normal

Low

Anti-thrombin III

Normal

Low

NRS Numeric Rating Scale for Pain; $n$ number
31.4

28.6

40

48.6

51.4

77.2

22.8

25.7

51.5

22.8

20

28.6

51.4

51.4

48.6

94.3

82.9

80

34.3

100

80.0

77.1

85.7

80.0

48.6

100

91.4

100

77.1

22.9

91.4

8.6

94.3

5.7 
Table 2 Mean and range of serum levels of protein C, protein S, and anti-thrombin III and comparison between both groups

\begin{tabular}{|c|c|c|c|}
\hline Variable & Group I (patients) & Group II (controls) & $p$ value \\
\hline Protein C (IU/dl) & & & 0.411 \\
\hline Mean \pm SD & $84.06 \pm 25.58$ & $87.60 \pm 13.21$ & \\
\hline Range & $29.00-174.00$ & $49.00-113.00$ & \\
\hline Protein S (IU/dl) & & & $0.009^{* *}$ \\
\hline Mean \pm SD & $84.77 \pm 11.68$ & $102.83 \pm 34.37$ & \\
\hline Range & $45.00-155.00$ & $68.00-124.00$ & \\
\hline $\begin{array}{l}\text { Anti-thrombin III } \\
(\mathrm{IU} / \mathrm{dl})\end{array}$ & & & $0.024^{*}$ \\
\hline Mean \pm SD & $96.20 \pm 12.45$ & $103.09 \pm 10.75$ & \\
\hline Range & $56.00-120.00$ & $82.00-124.00$ & \\
\hline
\end{tabular}

$S D$ standard deviation

*Significant; **highly significant

*Statistically significant at $p \leq 0.05$

Table 3 Comparison of brain MRI findings between the studied groups

\begin{tabular}{|c|c|c|c|c|c|}
\hline \multirow[t]{2}{*}{ Variable } & \multicolumn{2}{|c|}{ Group I (patients) } & \multicolumn{2}{|c|}{ Group II (controls) } & \multirow[t]{2}{*}{$p$ value } \\
\hline & $\begin{array}{l}\text { Number of } \\
\text { patients }\end{array}$ & $\%$ & $\begin{array}{l}\text { Number of } \\
\text { patients }\end{array}$ & $\%$ & \\
\hline \multicolumn{6}{|c|}{ Brain MRI findings } \\
\hline Normal & 28 & 80.0 & 35 & 100.0 & $0.011^{*}$ \\
\hline Abnormal & 7 & 20.0 & 0 & 0.0 & \\
\hline
\end{tabular}

*Significant

*Statistically significant at $p \leq 0.05$ detected between age, disease duration, headache frequency and headache intensity with serum levels of protein $\mathrm{S}$ or anti-thrombin III ( $p$-value $>0.05$ ).

There was a highly significant negative correlation between serum level of protein $S$ and brain MRI findings as deficiency of protein $\mathrm{S}$ is associated with the presence of abnormal findings in brain MRI of migraine patients $(p=0.001)$, however, no correlation was found between serum levels of protein $\mathrm{C}$ or anti-thrombin III and abnormal brain MRI findings $(p=0.672$, and 0.454 , respectively) (Table 6). A multivariate linear regression model revealed that serum protein $C$ deficiency is an independent predictor of migraine intensity grade $(p=0.021)$ (Table 7).

\section{Discussion}

Previous studies discussed the possible relationship between migraine, stroke and hypercoagulability syndromes. In this study, a statistically significant difference was found between migraine patients and normal subjects with regard to mean serum level of protein $S$ and anti-thrombin III, being significantly deficient in patients group, which goes in agreement with previous studies $[9$, 10].

In the current study, there was no statistically significant difference in mean serum level of protein $C$ between migraine patients and healthy controls, which agreed with previous studies done by Bassi et al. [11], Rajan et al. [12], D'Amico et al. [9], Cavestro and Mandrino [13] who reported that unlike protein $\mathrm{S}$ deficiency which has a

Table 4 Comparison of serum levels of protein C, protein S and anti-thrombin III between migraine patients with and without aura

\begin{tabular}{|c|c|c|c|c|c|}
\hline \multirow[t]{3}{*}{ Variable } & \multicolumn{4}{|c|}{ Migraine patients } & \multirow[t]{3}{*}{$p$ value } \\
\hline & \multicolumn{2}{|c|}{ With aura $(n=17)$} & \multicolumn{2}{|c|}{ Without aura $(n=18)$} & \\
\hline & Mean \pm SD & Range & Mean \pm SD & Range & \\
\hline Protein C (IU/dl) & $110.53 \pm 37.48$ & $52.00-174.00$ & $95.56 \pm 30.43$ & $29.00-165.00$ & 0.245 \\
\hline Protein S (IU/dl) & $87.59 \pm 31.05$ & $45.00-155.00$ & $80.72 \pm 19.41$ & $51.00-117.00$ & 0.503 \\
\hline \multirow[t]{2}{*}{ Anti-thrombin III (IU/dl) } & $95.24 \pm 9.54$ & $78.00-110.00$ & $97.11 \pm 14.92$ & $56.00-120.00$ & 0.405 \\
\hline & Number & $\%$ & Number & $\%$ & $p$ value \\
\hline \multicolumn{6}{|l|}{ Protein C } \\
\hline Normal & 13 & 76.5 & 14 & 77.8 & 1 \\
\hline Low & 4 & 23.5 & 4 & 22.2 & \\
\hline \multicolumn{6}{|l|}{ Protein S } \\
\hline Normal & 15 & 88.2 & 17 & 94.4 & 0.603 \\
\hline Low & 2 & 11.8 & 1 & 5.6 & \\
\hline \multicolumn{6}{|l|}{ Anti-thrombin III } \\
\hline Normal & 16 & 94.1 & 17 & 94.4 & 1 \\
\hline Low & 1 & 5.9 & 1 & 5.6 & \\
\hline
\end{tabular}

SD standard deviation; $n$ number 
Table 5 Correlation between age, disease duration, headache frequency and headache intensity with serum level of protein C, protein $\mathrm{S}$ and anti-thrombin III

\begin{tabular}{|c|c|c|c|c|c|c|}
\hline \multirow[t]{2}{*}{ Variables } & \multicolumn{2}{|l|}{$\begin{array}{l}\text { Protein C } \\
\text { (IU/dl) }\end{array}$} & \multicolumn{2}{|l|}{$\begin{array}{l}\text { Protein S } \\
\text { (IU/dl) }\end{array}$} & \multicolumn{2}{|c|}{ Anti-thrombin III (IU/dI) } \\
\hline & $\begin{array}{l}\text { Correlation } \\
\text { coefficient }(R)\end{array}$ & $p$ value & $\begin{array}{l}\text { Correlation } \\
\text { coefficient }(R)\end{array}$ & $p$ value & $\begin{array}{l}\text { Correlation } \\
\text { coefficient }(R)\end{array}$ & $p$ value \\
\hline Age & 0.289 & 0.092 & -0.247 & 0.153 & 0.206 & 0.235 \\
\hline Disease duration & 0.038 & 0.828 & -0.200 & 0.249 & 0.057 & 0.746 \\
\hline Headache frequency & 0.239 & 0.167 & -0.218 & 0.208 & -0.120 & 0.494 \\
\hline Headache intensity & 0.399 & $0.017^{*}$ & -0.067 & 0.701 & 0.269 & 0.118 \\
\hline
\end{tabular}

*Statistically significant at $p \leq 0.05$

Table 6 Correlation of serum levels of protein C, protein S, and anti-thrombin III with brain MRI findings

\begin{tabular}{ll}
\hline & Brain MRI findings \\
\hline Protein C (IU/dl) & \\
Correlation coefficient & -0.074 \\
$p$ value & 0.671 \\
Protein S (IU/dl) & \\
$\quad$ Correlation coefficient & -0.539 \\
$p$ value & $0.001^{* *}$ \\
Anti-thrombin III (IU/dl) & \\
Correlation coefficient & -0.135 \\
$p$ value & 0.440 \\
\hline
\end{tabular}

**Highly significant

high prevalence, the main problem of studying protein $\mathrm{C}$ deficiency is its very low prevalence in the general population $(0.14-0.40 \%)$. This usually requires larger sample sizes to detect any significant difference in prevalence between migraine patients and control group.

The present study showed no significant difference between MA and MO patients with regard to mean serum levels of protein $C$, protein $S$, or anti-thrombin III. This was in agreement with Martinez-Sanchez et al. [10], who reported that hypercoagulability had a higher frequency in MA patients (42.4\%) in comparison to MO patients (26.7\%); however, the difference was not statistically significant.

In the current study, a statistically significant difference was found between patients and controls with regard to the presence of abnormal MRI findings in form of ischemic foci and leukoareosis. This goes in accordance with studies done by Igarashi et al. [14], Swartz and Kern [15], and Kruit et al. [16] which revealed that migraine is associated with sub-clinical brain infarcts in MRI, suggesting that brain infarctions occur more frequently than expected in migraine patients. Three meta-analyses of observational studies also reflect that vascular risk is increased by twofold in migraine patients [17].

The prevalence of white matter hyper-intense lesions (WMHLs) in migraineurs was found to range from 6 to $40 \%$ [18]. This can be explained in many studies by other comorbidities such as age, hypertension, diabetes, or associated demyelinating diseases $[18,19]$. On the other hand, Swartz and Kern [15] demonstrated that migraine patients are close to four times more likely to show these WMHLs changes than age- and sex-matched controls. This increased risk was present even in young individuals who did not have any vascular risk factors or other disease comorbidities.

According to aura presence, this study showed no significant difference between MA and MO patients regarding brain MRI findings. Moreover, the serum protein levels were comparable in the two groups of

Table 7 Regression analysis to detect predictive value of protein C in migraine patients

\begin{tabular}{|c|c|c|c|c|c|c|c|}
\hline \multirow[t]{2}{*}{ Model } & \multicolumn{2}{|c|}{ Unstandardized coefficients } & \multirow{2}{*}{$\begin{array}{l}\text { Standardized } \\
\text { coefficients } \\
\text { Beta }\end{array}$} & \multirow[t]{2}{*}{$t$ value } & \multirow[t]{2}{*}{$p$ value } & \multicolumn{2}{|c|}{$95.0 \%$ confidence interval for $B$} \\
\hline & $B$ & Std. error & & & & Lower bound & Upper bound \\
\hline \multicolumn{8}{|l|}{ Protein C (IU/dl) } \\
\hline (Constant) & 36.379 & 27.888 & & 1.304 & 0.201 & -20.359 & 93.117 \\
\hline Migraine intensity & 9.156 & 3.769 & 0.389 & 2.429 & $0.021^{*}$ & 1.488 & 16.825 \\
\hline
\end{tabular}

*Significant

*Statistically significant at $p \leq 0.05$ 
patients with no significant difference, a finding which go in accordance with previous studies done by Fazekas et al. [19], Pavese et al. [20]. On the contrary, Ferbert et al. [21], Gozke and et al. [22] found a higher prevalence of brain ischemic lesions among MA patients. An increased risk of ischemic stroke was repeatedly reported in young subjects with migraine especially MA. This contradiction may be explained in view of the small sample size in this study.

In MA patients, Gursoy-Ozdemir et al. [23] suggested that cortical spreading depression (CSD) may cause disruption of the blood-brain barrier (BBB) through a matrix metalloproteinase-9-dependent cascade mechanism, which may result in local tissue damage. Moreover, Pezzini et al. [24] concluded that MO appears to be associated with hypercoagulability in the whole sample and in the transient ischemic attack (TIA) group, whereas MA is related to hypercoagulability in brain infarction patients under 50 years. One possible explanation was that some TIAs could actually be auras, and this may be acting as a confounding factor.

In this study, a statistically significant correlation was detected between serum protein S deficiency and abnormal brain MRI findings, however, no correlation was found between deficient serum protein $C$ or antithrombin III and brain MRI findings. This agreed with D'Amico et al. [9] who found that $6.4 \%$ of patients with ischemic strokes had low levels of protein $S$, suggesting that protein $\mathrm{S}$ deficiency can produce a state of hypercoagulability and induce stroke, at least when it is present in conjunction with other acquired or hereditary factors.

Anzola et al. [25] also found a relatively high prevalence of protein $\mathrm{S}$ deficiency in patients with previous ischemic strokes which highly suggested that the ischemic event might be related to the hypercoagulability caused by the decrease in free protein $\mathrm{S}$ levels.

The present study revealed that deficient serum protein $\mathrm{C}$ was an independent predictor of the severity of migraine headache. To the best of our knowledge, no previous researches studied this point.

\section{Conclusions}

The findings of this study provide an evidence of a link between migraine and hypercoagulability, which may indicate an increased risk for cerebral ischemic events in migraine patients. This may suggest adding prophylactic therapy to the management strategies of migraine patients, especially young patients, in order to prevent progression of ongoing hypercoagulability and decrease the risk of cerebral ischemic insults. However, the small number of patients is considered to be a limitation in our study and recommended to be applied on larger sample size in further studies.

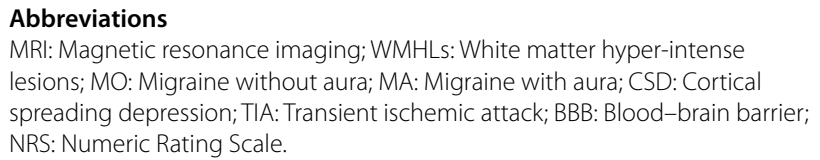

\section{Acknowledgements}

The authors acknowledge subjects for their participation and cooperation in this study.

\section{Authors' contributions \\ EMF: research idea, data acquisition, data analysis and interpretation. MS: collection of samples from the studied groups. RMM: data acquisition, data analysis and interpretation. HME: data acquisition, data interpretation and manuscript writing and reviewing. All authors have read and approved the final manuscript.}

Funding

This research received no specific grant from any funding agency in the public, commercial, or not-for-profit sectors.

\section{Availability of data and materials}

The datasets generated and/or analyzed during the current study are not publicly available due to the current Cairo University regulations and Egyptian legislation but are available from the corresponding author on reasonable request and after institutional approval.

\section{Declarations}

\section{Ethics approval and consent to participate}

An informed written consent was taken from each patient. All data obtained from every patient were confidential and were not used outside the study. The patients have rights to withdraw from the study at any time without giving any reason. All the costs of the investigations were afforded by the researcher. Our study was approved by ethical committee of the Department of Neurology, Faculty of Medicine, Cairo University, on 8/7/2020 (code MS-92-2020).

\section{Consent for publication}

Not applicable.

\section{Competing interests}

The authors declare that they have no competing interests.

\section{Author details}

${ }^{1}$ Neurology Department, Faculty of Medicine, Cairo University, Cairo, Egypt. ${ }^{2}$ Clinical Pathology Department, Faculty of Medicine, Cairo University, Cairo, Egypt.

Received: 28 May 2021 Accepted: 17 November 2021

Published online: 04 January 2022

\section{References}

1. Headache Classification Committee of the International Headache Society (IHS). The international classification of headache disorders, 3rd edition. Cephalalgia. 2018;38(1):1-211.

2. Bousser MG, Welch KMA. Relation between migraine and stroke. Lancet Neurol. 2005;4(9):533-42.

3. Tietjen GE, Collins SA. Hypercoagulability and migraine. Headache. 2018;58(1):173-83.

4. Thomas RH. Hypercoagulability syndromes. Arch Intern Med. 2001;161(20):2433-9. 
5. Pepler L, Wu C, Dwivedi DJ, Wu C, Kim PY, Liaw PC. The impact of the endothelial protein $C$ receptor on thrombin generation and clot lysis. Thromb Res. 2017;152:30-7.

6. Chaudhry SR, Lendvai IS, Muhammad S, Westhofen P, Kruppenbacher J, Scheef $L$, et al. Inter-ictal assay of peripheral circulating inflammatory mediators in migraine patients under adjunctive cervical non-invasive vagus nerve stimulation (nVNS): a proof-of-concept study. Brain Stimul. 2019;12(3):643-51.

7. Loder $E$, Burch R. Measuring pain intensity in headache trials: which scale to use? Cephalalgia. 2012;32(3):179-82.

8. Flieder T, Gripp T, Knabbe C, Birschmann I. The Sysmex CS-5100 coagulation analyzer offers comparable analytical performance and excellent throughput capabilities. Pract Lab Med. 2016;6:38-47.

9. D'Amico D, Moschiano F, Leone MA, Ariano C, Ciusani E, Erba N, et al. Genetic abnormalities of the protein $C$ system: shared risk factors in young adults with migraine with aura and with ischemic stroke. Cephalalgia. 1998;18(9):618-21.

10. Martinez P, Martinez M, Fuentes B, Cuesta MV, Cuellar-Gamboa L, IdrovoFreire $L$, et al. Migraine and hypercoagulable states in ischemic stroke. Cephalalgia. 2011:31(16):1609-17.

11. Bassi B, Parodi E, Messina M, Boffi P, Bobba B, Campagnoli MF, et al. Screening for genetic and acquired thrombophilia in a cohort of young migrainous patients. J Headache Pain. 2003;4(3):138-45.

12. Rajan R, Ahluwalia J, Lal V. Prothrombotic states in migraine. Clin Appl Thromb Hemost. 2014;20(8):851-6.

13. Cavestro C, Mandrino S. Thrombophilic disorders in migraine. Front Neurol. 2014:5:120.

14. Igarashi H, Sakai F, Kan S, Okada J, Tazaki Y. Magnetic resonance imaging of the brain in patients with migraine. Cephalalgia. 1991;11:69-74.

15. Swartz RH, Kern RZ. Migraine is associated with magnetic resonance imaging white matter abnormalities: a meta-analysis. Arch Neurol. 2004;61:1366-8

16. Kruit MC, Launer $L$, Ferrari MD, van Buchem MA. Infarcts in the posterior circulation territory in migraine. The population-based MRI Camera Study. Brain. 2005;128:2068-77.

17. Spector JT, Kahn SR, Jones MR, Jayakumar M, Dalal D, Nazarian S. Migraine headache and ischemic stroke risk: an updated meta-analysis. Am J Med. 2010;123:612-24.

18. De Benedittis G, Lorenzetti A, Sina C, Bernasconi V. Magnetic resonance imaging in migraine and tension-type headache. Headache. 1995;35(5):264-8.

19. Fazekas F, Koch M, Schmidt R, Offenbacher H, Payer F, Freidl W. The prevalence of cerebral damage varies with migraine type: a MRI study. Headache. 1992;32:287-91.

20. Pavese N, Canapicchi R, Nuti A, Bibbiani F, Lucetti C, Collavoli P, et al. White matter MRI hyper-intensities in a hundred and twenty-nine consecutive migraine patients. Cephalalgia. 1994;14:342-5.

21. Ferbert A, Busse D, Thron A. Microinfarction in classic migraine? A study with magnetic resonance imaging findings. Stroke. 1991;22:1010-4.

22. Gozke E, Ore O, Dortcan N, Unal Z, Cetinkaya M. Cranial magnetic resonance imaging findings in patients with migraine. Headache. 2004:44:166-9.

23. Gursoy Y, Qiu J, Matsuoka N, Bolay H, Bermpohl D, Jin H, et al. Cortical spreading depression activates and upregulates MMP-9. J Clin Invest. 2004;113:1447-55.

24. Pezzini A, Grassi M, Lodigiani C, Patella R, Gandolfo C, Casoni F, et al. Predictors of migraine subtypes in young adults with ischemic stroke: the Italian project on stroke in young adults. Stroke. 2011;42(1):17-21.

25. Anzola GP, Magoni M, Ascari E, Maffi V. Early prognostic factors in ischemic stroke. the role of protein $\mathrm{C}$ and protein S. Stroke. 1993;24(10):1496-500.

\section{Publisher's Note}

Springer Nature remains neutral with regard to jurisdictional claims in published maps and institutional affiliations.

\section{Submit your manuscript to a SpringerOpen ${ }^{\circ}$ journal and benefit from:}

- Convenient online submission

- Rigorous peer review

- Open access: articles freely available online

- High visibility within the field

- Retaining the copyright to your article

Submit your next manuscript at $\boldsymbol{\nabla}$ springeropen.com 